\title{
Revitalization of Creative Industries and City Branding: Competitiveness and Productivity in Knitted Industry Perspective
}

\author{
${ }^{1}$ DEDEN SUTISNA, ${ }^{2}$ BENNY YUSTIM, ${ }^{3}$ NUGROHO J STIADI \\ 1,3 Business and Management Faculty, Widyatama University, Bandung. \\ 2 Enginering Faculty, Widyatama University, Bandung. \\ email: ${ }^{1}$ deden.sutisna@widyatama.co.id; ${ }^{2}$ byustim@gmail.com; ${ }^{3}$ nstiadi919@gmail.com
}

\begin{abstract}
The development of creative industries in Bandung, Indonesia showed a quite satisfactory improvement. This success needs to be completed by performing revitalization and city branding for Bandung. This study aims to examine the factors of competitiveness and productivity in the knitted industry of Binong Jati in the revitalization of creative industries and city branding in Bandung, West Java Province. The research used census method and verification with statistical method of Confirmatory Factor Analysis. The unit of analysis is thirty people of owners or knitted creative business entrepreneurs in Bandung city. The result of this research is that out of twenty-eight factors studied, the dominant factor of industrial competitiveness is drawn to seven factors which are the production equipment used, the owner quick response, the product trend periods, knitting machine used, the processed of raw material, delivery of goods, and workers with accuracy. There are four factors of productivity and one dominant factor is flexibility.
\end{abstract}

Keyword: Competitiveness, Revitalization, City Branding

\section{Introduction}

Almost all countries, especially countries with societal base, are relying on the economy of agricultural sector. The agricultural sector has a strategic role in recruiting or gaining employment and also being national food provider. Nevertheless, a series of problems in the process of agricultural development still cannot be fully resolved, especially when it is related to vulnerability of poverty on farmers in rural area (Dumasari and Tri Septin Muji Rahayu, 2016, p 175 ). It is small and medium industry that has become one of the drivers of the country's economic growth. This sector becomes easier and has a potential to be developed since the resources have already existed. Fisla Wirda stated in Mimbar Journal on June ( 2016, p 126 ) " the role of creative industries to GDP in many countries show significant effect, for example in the UK 7,9\%, in Australia 3,3\%, in New Zealand 3,1\%, and Singapore $2,8 \%$, while in Indonesia it is 6,9 and able to absorb 5,8\% of the workforce". The contribution of small-scale enterprises in exports to ASEAN countries appears as in
Table 1.

Tabel 1

Small Busines segment of exports in developing countries (1990 - 2015)

\begin{tabular}{ll}
\hline Countries & $\begin{array}{l}\text { Average } \\
\text { Segments }\end{array}$ \\
\hline Thailand & $10-40$ \\
Philippines & $20-25$ \\
Vietnam & 20 \\
Indonesia & $20 *$ \\
Singapore & 16 \\
Malaysia & $10-15$ \\
*: only in manufacture & \\
industry & \\
\hline
\end{tabular}

Source: Dhanny Septimawan Sutopo, ( 2016, p 414 )

The development of creative industries in Bandung, Indonesia showed a quite satisfactory improvement. So far, there are strategic production areas in Bandung City, including 33 creative industrial centers with seven major industrial centers consist of:

Received: December 18, 2017, Revision: April 25, 2017, Accepted: June 04, 2018

Print ISSN: 0215-8175; Online ISSN: 2303-2499. DOI: http://dx.doi.org/10.29313/mimbar.v34i1.3308.166-175

Accredited B based on the decree No.040/P/2014, valid on February, 18, 2014 until February, 18, 2019. Indexed by DOAJ, Sinta, IPI 
(1) Shoes and Leather centre in Cibaduyut; (2) Jeans (denim) Cihampelas centre; (3) Cigondewah Textile Center; (4) Shirt centre in Surapati; (5) Tahu and Tempe centre in Cibuntu; (6) Doll centre in Sukamulya; and (7) Textile woven centre in Binong Jati.

Knitted industry in Binong Jati, Bandung is originally conducted for generations and started since the 1960 s by some people in Binong Jati residents who had worked in a knitting factory owned by Chinese businessmen in Bandung. Armed with knitting skills, they finally start a similar business in their home areas of Binong Jati as a home industry. At first, this business was only occupied by some people until finally began to develop until now and give impact to economy of society which originally depended on agriculture sector.

In its development, the labor-intensive industry of Binong Jati Industrial Center currently experienced a decrease number of crafters which led to a decreased number of workers absorbed. Table 2 shows the detail.

\section{Table 2}

\section{Number of Knitted Crafters and Workers at Binong Jati Knitted Industry}

\begin{tabular}{|c|c|c|}
\hline Years & $\begin{array}{c}\text { Business } \\
\text { Number } \\
\text { (Crafters) }\end{array}$ & $\begin{array}{c}\text { Workers } \\
\text { Number } \\
\text { (employees) }\end{array}$ \\
\hline 2012 & 293 & 2143 \\
\hline 2013 & 140 & 1680 \\
\hline 2014 & 120 & 1440 \\
\hline 2015 & 100 & 1000 \\
\hline
\end{tabular}

Source: Industries Cooperative Knitted Binong Jati

(KIRBI)

The table above shows that the role of small industry including creative industry in Indonesia is still small.

Indonesia's economic growth in quarterly basis tends to increase from $4.73 \%$ in the third quarter of 2015 to $5.04 \%$ in the fourth quarter of 2015. This means the acceleration of economic growth occurred in fourth quarter of 2015 compared to the previous quarters. However, if viewed annually, Indonesian economic growth continues to slow. Referring to the Central Bureau of Statistics (BPS) note, Indonesian economic growth of 2015 of 4.79 $\%$ is the lowest for the last six years, affecting the coming years of 2016 and 2017.

Binong Jati Knitted has an annual production capacity of 852,200 dozen with investment value of Rp.31,366 billion and absorbs 2,143 employees. Given the large number of labor that can be absorbed and the velocity of money is large enough that can prosper the community in this industry, it is very unfortunate if the center of this knitting industry have to setback. Moreover, the great potential of this industry center to become a shopping center, study, and industry for tourists who can provide income to the city of Bandung is also a strong reason that this center should still exist and grow and achieve again the times of glory. Therefore, a revitalization is needed to be performed and create one city branding for city of Bandung.

The Model Competitiveness Diamond (Porter, 1990), says that the industry in a superior area is not of its own accord but a group's success with the inter-linkages between companies and supporting institutions. In the industrial cluster, the companies involved not only large and medium enterprises, but also small companies. Porter (1990) introduces the theory of competitive ability of a country described in the diamond model as seen in figure1.

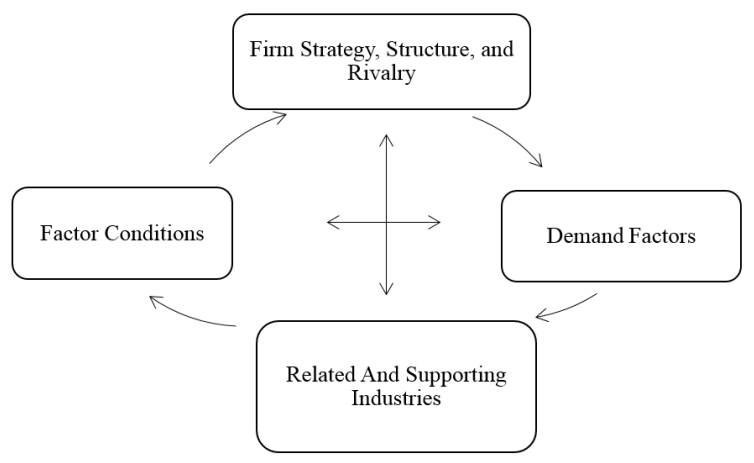

Figure 1. Diamond of Porter Model

Ward et al (1998) opinion on the competitiveness dimension of a product comprised of cost, quality, delivery time, and flexibility. According to Fisla Wirda (2016), et.al in Mimbar Journal June 2016, there are five categories of competitive advantage, which are a) low-cost strategy, b) broaddifferentiation strategy, c) best-cost provider strategy, d) focused on market niche strategy based on low-cost, e) focused on market niche strategy based on differentiation by offering a product or service to members who consume base on taste and need. These four dimensions are further explained by Suhardi (2007) with the following indicators: (a) Cost is the dimension of operational competitiveness which includes three indicators namely 
production cost, labor productivity, and the use of production capacity and inventory; (b) Quality is an important dimension of operational competitiveness which includes a variety of indicator such as product display, product acceptance period, product durability, and quick response of consumer complaints settlement; (c) Delivery time is a competitiveness dimension covering wide range indicators such as timeliness of production, reduction of waiting time production, and timeliness of product delivery; (d) Flexibility is a dimension of operational competitiveness that includes various indicators such as product range and speed adjust to environmental interests.

Furthermore, other factors that influence competitiveness are (1) Location: A strategic business location will attract buyers. According to Frans Gana (2003), location will be very important as a place for customers to visit and easily find the product they need. Customers would like to take the shortest mileage to go to the store, although there is possibility for distance costumers to come, but only in small percentage; (2) Price: According to Sunarto (2004), price factor also affects a buyer to make decisions. Price is the value of a product or service measured by the amount of money. In order to get the desired product or service, customers must be willing to pay some money. Sensitive customers usually take low price as an important source of satisfaction because they will get high value for money (Basu, 2008); (3) Service: Service through product means the customer is served completely through the inventory of existing and quality products; (4) Promotion: Sunarto (2004) states that sales promotion consists of short-term incentives to encourage the spending or selling of products or services.

According to L. Greenberg (2009), productivity is a comparison between the totality of exposure at a given time divided by the totality of inputs during the period. According to As'ad (2009), the concept of productivity is associated with the effectiveness of: (1) Relation between modern and classical organizational theories of output and input; (2) Assuming effectiveness as a comparison/level in which the objectives presented can be considered achievable; (3) External effectiveness or comparison between environmental evaluation of one unit of output and one unit of input; (4) The ability of the system to continue to adapt and evolve regardless the specific objectives to be achieved.
In the doctrine of the Oslo Conference as stated by As'ad (2009), there is a general definition of universal productivity: "Productivity is a universal concept which aims to provide more goods and services for more people using less real resource."

Based on these opinions, it can be said that the productivity of workforce production is an interdisciplinary approach to determine effective goals, plan-making, application of productivity that used efficiently, and to maintain high quality. Productivity involves the efficient utilization of human resources and skills, technological capital goods, management, information, energy, and other resources leading to the development and upgrading of living standards for the whole society through the concept of total universe productivity.

Michael Porter explicitly states productivity is the root determinant of competitiveness at the level of individuals, companies, industries, and country's scale. Productivity itself is a source of living standards as well as individual income sources and per capita income. While competitiveness is basically the ability to create a level of prosperity. The $\operatorname{OECD}(2009)$ defines competitiveness as a level of a country's ability to produce goods and services in accordance with international market demands and at the same time gain the ability to create sustainable prosperity for its citizens. So there is a corresponding relationship between the level of productivity and the level of competitiveness.

Based on the above background research, the problem that can be identified is: what factor is the most dominant to influence the competitiveness in increasing industrial productivity of Binong Jati creative knitted as an element that needs to be revitalized.

This study is expected to have the following benefits: (1) for the industrial knitted center of Binong Jati, this research is expected to provide useful information that can be used as input to increase the productivity; (2) for RISTEKDIKTI, this research can be used as one of the basis for further research development related to revitalization of creative industry, especially human resource competitiveness; (3) for education, this research is expected to provide reference materials for readers who study creative economics, especially in the aspect of human resources. 


\section{Methods}

The object of this research is productivity competitiveness at Binong Jati knitted industry. It is one of the potential creative industries in Bandung, located at Jl. Binong Jati, Batununggal, Bandung City, West Java 40275. Binong Jati knitting industry has been declared cooperative office and small business in trade city of Bandung as a textile industry area. That area produced various kinds of knitted products such as sweaters, cardigans, sweaters, jackets, and others made of yarn and fabric. Analysis unit in this study is 30 owners or managers of the knitting business at the knitted industrial center Binong Jati, Bandung. Data of craftsmen/owners in Binong
Jati knitted industry considered as population and sample with detail data shown in Table 3.

The 30 owners above are active craftsmen who have a running well business turnover and product order.

The method in this research is census and verification (Riduwan, 2012), by way of descriptive research and verification. Analyzer used in this research is qualitative and quantitative analysis. Qualitative analysis uses frequency data analysis with criteria using interval class, while for quantitative analysis using confirmatory factor analysis for both dominant factor and contribution (Ghozali, 2011). Data obtained by ordinal scale with test data validity, reliability,

Table 3

Data of Industrial Knitted Crafters at Binong Jati Bandung

\begin{tabular}{|c|c|c|c|c|}
\hline No & Industrial Name & Owner & Adress & $\begin{array}{l}\text { Phone } \\
\text { Number }\end{array}$ \\
\hline 1 & Tiara Sweater & Agam Subanda & Jl. Binong Jati Rt. 01/04 No. 41 D & 081312903619 \\
\hline 2 & Gubank Collection & Agus & $\begin{array}{l}\text { Jl. Ibrahim Ajie Gg. Mesjid No. } 26 \\
\text { Rt. 06/05 }\end{array}$ & 081220000696 \\
\hline 3 & Javedstore & Afni Pratiwi & Jl. Sarijadi blok. 7 No. 64 & 087722036606 \\
\hline 4 & Alvina Collection & Cepi Andriana & Jl. Binong Jati No. 70 & 081320762855 \\
\hline 5 & Karimake & Eka Rahmat Jaya & Jl. Binong Jati & 085624010106 \\
\hline 6 & Vuxer & Ilham & Jl. Dr. Djunjunan 555 & 082218989723 \\
\hline 7 & WaninaClothing & Wahyudin & Jl. Binong Jati No.127 & 082240925321 \\
\hline 8 & DP. Collection & Asep DP. & Jl. Binong Jati & 08172389435 \\
\hline 9 & Adilla Mecca & Rudi Ruswandi & Jl. Binong Jati No. 124 & 085220314848 \\
\hline 10 & Chonk Collection & Achonk & Jl. Binong Jati & 082295029789 \\
\hline 11 & Ashpy Desain & Asep Sumarna & Jl. Binong Jati Rt. 03/ 04 & 08122342036 \\
\hline 12 & Ejaya Collection & Edi & Gg. Masjid No. 28 & 081220470502 \\
\hline 13 & Reska Home Industri & Azmi & Jl. Cikadut & $\begin{array}{l}0898377577 / \\
081220120030\end{array}$ \\
\hline 14 & CV. Rahaja Putra & Abzlul Rohman & Ds. Cikaso Kec. Kramat Mulya & 08977019731 \\
\hline 15 & Elvira Miranda Collect & Elvira Miranda & Kopo Permai II/ B2-1 BDG & 081323959543 \\
\hline 16 & Amiza Hand Made Coll & Lusi Windianti & Jl. Karya No. 21 Rt. 03/01 Cimindi & 081220063983 \\
\hline 17 & Penni_olshop, Hiicult & Penni Juwita Sari & Jl. Binong Jati Gg. Mahfud No.9 & 082240306836 \\
\hline 18 & Penni_olshop, Hiicult & Vinna & Jl. Sukanigon 19 & 081222205281 \\
\hline 19 & Penni_olshop, Hiicult & Yulia Ulfah & Jl. A.H. Nasution No. 962/ 4 & 085294077719 \\
\hline 20 & Penni_olshop, Hiicult & Lina & Jl. H. Topek No. 19 C & 081910261617 \\
\hline 21 & Penni_olshop, Hiicult & Gunawan & Jl. Binong Jati & 082221528281 \\
\hline 22 & CV. Ahyor Sugenra & Maman Hermawan & Jl. Binong Jati No. 8 128/B & 081321089349 \\
\hline 23 & Ashpy & Asep S. & Jl. Binong Jati & 087722117667 \\
\hline 24 & Adilla Mecca & Yoga Jaya & Jl. Binong Jati No. 124 & 082214932220 \\
\hline 25 & Tridi Store & $\begin{array}{l}\text { Irwan Setiawan/ } \\
\text { Anne }\end{array}$ & Jl. Binong Jati No.79 & 08782470855 \\
\hline 26 & Ketcozknits & Danny Ipung & Jl. Binong Jati & 08888716838 \\
\hline 27 & Knittbyme & Ria Ariyani & $\begin{array}{l}\text { Jl. Binong Jati Gg. Saad } 3 \text { Rt. } \\
09 / 04\end{array}$ & 085861614971 \\
\hline 28 & Asphy Desain & Asep Sumarna & Jl. Binong Jati Rt. 03/04 & 08122342036 \\
\hline 29 & Amel & Carles Ginting & Jl. Binong Jati No. 128 & 08122328322 \\
\hline 30 & Ayu Collection & Aang Nasrulloh & Jl. Binong Jati No. 129 & 081572062494 \\
\hline
\end{tabular}


normality and classical assumptions.

\section{Data Analysis}

Based on the research results in analysis unit and the analysis object of Competitiveness and Productivity of Knitted Creative Industry in Binong Jati, the data and information obtained can be analyzed as follows:

\section{Descriptive Analysis Results for Com- petitive Conditions}

Descriptive condition of human resources competitiveness can be seen from indicator used to yield information as in Table 4 which require more attention from competent party.

Based on the 4 dimensions examined for the condition of competitiveness, Binong Jati knitted creative industry has good criteria. More detailed results can be explained as follows: (1) Human resources costs related to production costs have a value of 3.56 , worker productivity is 4.13 , and the use of production capacity and inventory is 4.18 with an average of 3.96. The average value is included in either criterion because it is at the interval of $3.40-4.19$. This means that workers' resources in the knitting creative industry are assessed good and supportive; (2) The quality of production produced by business actors is in very good category (average 4.36). Indicators included into these dimensions are output model generated (4.42), product receipt time delivered (4.33), resulting product resistance (4.35), completeness and resulting product component (4.32); (3) the timing of results delivery and orders made by the business actor is currently timely (average 4.19), the timeliness given (4.08), the production waiting time (4.22), the waiting time of production (4.19) is in criterion of 3.40 to 4.19 ; (4) The degree of flexibility of products produced by the industry has excellent condition (4.34) because it is supported by a very good production diversity (4.58) and product adjustment with excellent environmental change (4.42).

\section{Results of Descriptive Analysis for Creative Industries Productivity con- ditions}

The descriptive condition of human resource productivity can be seen from indicator used to yield information as in Table 5.

Table 5

Recapitulation of Knitted Creative Industry Productivity

\begin{tabular}{|l|l|c|c|}
\hline No & Dimension & Average & Criteria \\
\hline 1 & Employee Result & 4,10 & Good \\
\hline
\end{tabular}

Table 4

Condition of Knitted Creative Industry Competitiveness

\begin{tabular}{|c|l|l|c|c|}
\hline No & Dimension & Indicator & Average & Criteria \\
\hline 1 & Dimension of HR Cost & Production Cost & 3,56 & Good \\
\hline & & Worker productivity & 4,13 & Good \\
\hline & & Production Capacity Uses and inventory & 4,18 & Good \\
\hline 2 & $\begin{array}{l}\text { Production Quality } \\
\text { Dimension }\end{array}$ & Product Styles & 3,96 & Good \\
\hline & & Product Acceptance Period & 4,42 & Very Good \\
\hline & & Product Durability & 4,33 & Very Good \\
\hline & & Completion Rate of Consumer Complaint & 4,35 & Very Good \\
\hline & & Average & 4,32 & Very Good \\
\hline 3 & Delivery Time & Production Timeliness & 4,08 & Very Good \\
\hline & & Reduction of Waiting Time Production & 4,22 & Good \\
\hline & & Timeliness Product Delivery & 4,27 & Very Good \\
\hline 4 & Flexibility & Average & 4,19 & Good \\
\hline & Various Product Produced & 4,58 & Very Good \\
\hline & $\begin{array}{l}\text { Adjusted Quick Adaption with environment } \\
\text { urgent }\end{array}$ & 4,42 & Very Good \\
\hline & Average & 4,50 & Very Good \\
\hline
\end{tabular}




\begin{tabular}{|l|l|c|c|}
\hline 2 & $\begin{array}{l}\text { Quantity of Employee } \\
\text { works }\end{array}$ & 4,22 & $\begin{array}{l}\text { Very } \\
\text { Good }\end{array}$ \\
\hline 3 & $\begin{array}{l}\text { Time and Speed } \\
\text { of Employment to } \\
\text { complete work }\end{array}$ & 4,20 & $\begin{array}{l}\text { Very } \\
\text { Good }\end{array}$ \\
\hline & Average & 4,17 & Good \\
\hline
\end{tabular}

The average yield of 4.17 for the productivity condition at Binong Jati knitting industry shows good condition. Productivity result is good seen from the results of workers in the sector because it has value 4.10 with good criteria. Number of workers and their accuracy in completing the output are assessed good because its value is 4.22 and 4.20.

\section{Analysis of Factors Determining Competitiveness in Increasing Pro- ductivity of Binong Jati Knitted Cre- ative Industry (Study at Creative Industry Center Knitted)}

Analysis test is conducted using confirmatory factor analysis to determine which factors are dominant from variables of 1) cost, 2) quality, 3) delivery time, and 4) flexibility to knitted creative industry productivity and aimed to confirm or test the measurement model. Before confirmatory factor analysis is carried out, firstly there was a test for validity, reliability, normality, and classical assumption data. The test results indicate that the data is valid/reliable, normal, and meet the classical assumption.

\section{Factors Analysis}

In order to see the most influential factors of the 4 components, namely: 1) cost, 2) quality, 3) delivery time, and 4) flexibility, productivity of knitting creative industry consists of 28 statement items, of which 3 indicators used to measure cost, 4 indicators to measure quality, 3 indicators to measure delivery time, 2 indicators to measure flexibility, and 3 indicators to measure the productivity of the knitting creative industry. The result of the analysis is elaborated in explanation below.

\section{Analysis of KMO and Bartlett's Test}

The correlation test results among independent variables are in KMO (Kaisser Meyer-Olkin and Bartlett's) Test Output as in Table 6:
Table 6

KMO and Bartlett's Test

\begin{tabular}{|c|l|c|}
\hline Number & Descript Analysis & Result \\
\hline 1 & $\begin{array}{l}\text { Kaiser-Meyer-Olkin } \\
\text { Measurement }\end{array}$ &, 512 \\
\hline 2 & $\begin{array}{l}\text { Baertlett's Test of } \\
\text { Sphericity Approx } \\
\text { Chi-Square }\end{array}$ & 699,603 \\
\hline 3 & Df & 378 \\
\hline 4 & Sig &, 000 \\
\hline
\end{tabular}

The KMO and Bartlett's Test values for the correlation between the desired variables are $>0.5$. The significance of the study was 0.05 . From the table 5 results obtained $\mathrm{KMO}$ value of 0.512 which means greater than 0.5 . Meanwhile, the significance result from Bartlett's Test of Sphericity is 0.000 . From table 5 results, it can be stated that the variables used allow for further analysis. Furthermore, to see the correlation between variable cost, quality, delivery time, and flexibility as well as productivity of knitting creative industry can be considered in AntiImage Matrices analysis result.

\section{Total Variance Explained Analysis}

This analysis presents the results of research in the form of determining the components (factors) that are analyzed or maintained. The results of the table 7 can help to elaborate the analysis.

\section{The Explanation of table 6 analysis:}

\section{Eigenvalue Criteria}

To determine the component (factor) analyze (defend), we must look at the value of Eigenvalue and variance from the calculation results of this factor analysis which explains the amount of variable relationship altogether (total variance) to the factor (further referred to as component). The Eigenvalue and variance values are used as the basis for determining the number of feasible components to be taken as components representing the variables analyzed. The Eigenvalue and variance values can be seen in the above table showing the fifteen variables that can be processed and the total number of variance (cumulatively) of some of the components maintained. Table of total variance explained further shows the things as follows:

The first column is the result of factor 
analysis of 28 variables data (questionnaire items), of which the data shows seven components that can be maintained, ie the components that have eigenvalue value more than 1. Component one has eigenvalue of 11.394 , component two is 2,515 , component three is 2,382 , component four is 2,117 , component five is 1,526 , component six is 1.239 , and component seventh is 1.043 .

Thus, the factors have been formed by paying attention to Anti-images Matrices table. However, more explanation can be found in the table 8.

The second column is the calculation result of data factor analysis. Out of 28 variables (question items) of data being examined four components are drawn can be maintained, that is the component with eigenvalue value of 1 . Component one of eigenvalue value is equal to 4,743 .

\section{Extraction Method: Principal Compo- nent Analysis.}

Component matrix process is formed only 1 piece of component (see table 9 of Component Matrix), that is for indicators of 1) Machine/production equipment that is fully used according to order capacity, 2) The product that produced is made from appropriate material standard order, 3) Trend period/model of a product is last long enough, 4) Knitting machine used to meet production targets and rarely experience jammed, 5) Raw materials (yarn) to be processed always available according to number of orders and avoid waiting , 6 ) Delivery of goods using the help of other parties such as shipping services (expedition, cargo, package) and 7) Workers have timeliness in working orders that have been provided.

Table 7

Total Variance Explained

\begin{tabular}{|c|c|c|c|c|c|c|}
\hline \multirow[b]{2}{*}{ Component } & \multicolumn{3}{|c|}{ Initial Eigenvalues } & \multicolumn{3}{|c|}{ Extraction Sums of Squared Loadings } \\
\hline & Total & $\begin{array}{c}\% \text { of } \\
\text { Variance }\end{array}$ & $\begin{array}{c}\text { Cumulative } \\
\%\end{array}$ & Total & $\begin{array}{c}\text { \% of } \\
\text { Variance }\end{array}$ & $\begin{array}{c}\text { Cumulative } \\
\%\end{array}$ \\
\hline 1 & 11.394 & 40.694 & 40.694 & 11.394 & 40.694 & 40.694 \\
\hline 2 & 2,515 & 8981 & 49.675 & 2,515 & 8.981 & 49675 \\
\hline 3 & 2.382 & 8.509 & 58.184 & 2.382 & 8.509 & 58.184 \\
\hline 4 & 2.117 & 7.56 & 65744 & 2.117 & 7.56 & 65,744 \\
\hline 5 & 1526 & 5451 & 71195 & 1,526 & 5.451 & 71195 \\
\hline 6 & 1.239 & 4.423 & 75.618 & 1.239 & 4,423 & 75.618 \\
\hline 7 & 1043 & 3726 & 79.344 & \multirow[t]{22}{*}{1,043} & \multirow[t]{22}{*}{3.726} & \multirow[t]{22}{*}{79,344} \\
\hline 8 & 0.946 & 3.378 & 82.723 & & & \\
\hline 9 & 0.714 & 2548 & 85.271 & & & \\
\hline 10 & 0.69 & 2.465 & 87736 & & & \\
\hline 11 & 0.597 & 2.132 & 89.869 & & & \\
\hline 12 & 0.523 & 1869 & 91.737 & & & \\
\hline 13 & 0.404 & 1443 & 93.18 & & & \\
\hline 14 & 0.335 & 1.197 & 94377 & & & \\
\hline 15 & 0.31 & 1105 & 95.482 & & & \\
\hline 16 & 0,246 & 0.88 & 96.362 & & & \\
\hline 17 & 0,193 & 0.69 & 97.053 & & & \\
\hline 18 & 0,179 & 0.638 & 97.691 & & & \\
\hline 19 & 0,157 & 0,562 & 98252 & & & \\
\hline 20 & 0,145 & 0,517 & 98769 & & & \\
\hline 21 & 0.114 & 0.408 & 99.178 & & & \\
\hline 22 & 0.073 & 0.261 & 99.439 & & & \\
\hline 23 & 0.054 & 0.194 & 99.633 & & & \\
\hline 24 & 0,43 & 0,155 & 99788 & & & \\
\hline 25 & 0.036 & 0.127 & 99.915 & & & \\
\hline 26 & 0,12 & 0.043 & 99.958 & & & \\
\hline 27 & 0.009 & 0.031 & 99.989 & & & \\
\hline 28 & 0.003 & 0.011 & 100,000 & & & \\
\hline
\end{tabular}


DEDEN SUTISNA, et al. Revitalization of Creative Industries and City Branding: Competitiveness...

Table 8

Total Variance Explained

\begin{tabular}{c|c|c|c|c|c|}
\hline Component & \multicolumn{3}{|c|}{ Initial Eigenvalues } & \multicolumn{2}{c|}{ Extraction Sums of Squared Loadings } \\
\cline { 1 - 3 } & Total & $\%$ of Variance & Cumulative \% & $\begin{array}{c}\text { Total } \\
\text { Variance }\end{array}$ & Cumulative \% \\
\cline { 3 - 5 } 1 & 4,743 & 59,284 & 59,284 & 4,743 & 59,284 \\
2 &, 923 & 11,536 & 70,820 & 59,284 & \\
3 &, 590 & 7,381 & 78,201 & & \\
4 &, 558 & 6,973 & 85,174 & & \\
5 &, 405 & 5,059 & 90,233 & & \\
6 &, 296 & 3,703 & 93,935 & & \\
7 &, 278 & 3,480 & 97,416 & & \\
\hline
\end{tabular}

Extraction Method: Principal Component Analysis.

Table 9

Component

\begin{tabular}{|l|l|}
\hline Item & Component \\
\hline X1.9 & 40,694 \\
\hline X2.7 & 49,675 \\
\hline X2.8 & 58,184 \\
\hline X3.2 & 65,744 \\
\hline X3.4 & 71,195 \\
\hline X3.6 & 75,618 \\
\hline X4.4 & 79,344 \\
\hline
\end{tabular}

Dominant factors that are formed: 1) For the factor of flexibility, there is one component selected as a factor that can affect the competitiveness in improving the productivity of Binong Jati knitted creative industry, that is the indicator of quick adjustments to the environmental interests. The statement is on point 4 with a result of 79.344. 2) On time delivery factor, there are three components selected as factors that can affect the competitiveness in improving the productivity of the Binong Jati knitting creative industry, namely the indicator of timeliness of product delivery, reduction of production waiting time, and timeliness of production. The statement is on point 6 with the result is 75,618 , on point 4 with the result equal to 71,195 and on point 2 with a result equal to $65,744.3)$ The quality factor, there are two components selected as factors that can affect the competitiveness in improving the productivity of knitting creative industry, namely the indicator of quick response to complaints and consumer resilience products endurance. The statement is on point 8 with the result of 58.184 and on point 7 with the result of 49.675 .4 ) In cost factor, there is one component selected as a factor that can affect the competitiveness, i.e the indicator of the use of production and inventory capacity and the statement is on point 9 with the result of 40,694 . Based on the above explanation, statements can be grouped as in table 10 .

The conditions in the table 10 can be seen clearly in the rotated component plot image in the figure 2.

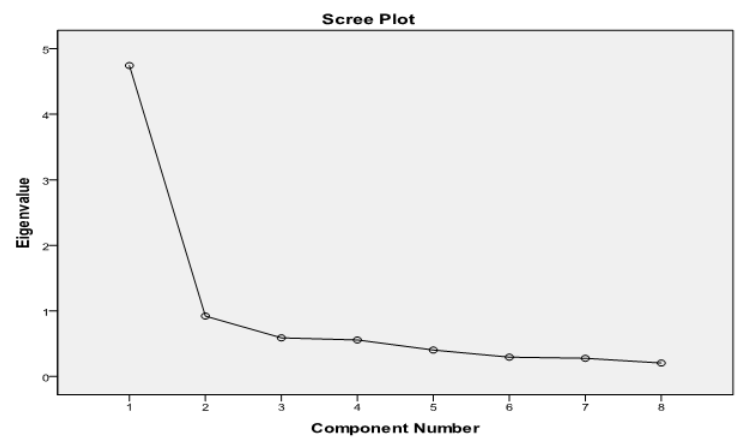

Figure 2. The Affecting Productivity Factors

The explanation for figure 2 can be described as in table 11.

The above table 10 can be explained by varying the Varimax Method: the spread 
Table 10

The Affecting Productivity Factors

\begin{tabular}{|l|l|l|l|}
\hline \multicolumn{1}{|c|}{$\mathbf{1}$} & \multicolumn{1}{|c|}{$\mathbf{2}$} & \multicolumn{1}{c|}{$\mathbf{3}$} \\
$\begin{array}{l}\text { Machine/production } \\
\text { equipment used in full } \\
\text { order capacity (order) }\end{array}$ & $\begin{array}{l}\text { Trend period/model of } \\
\text { a product that last long } \\
\text { enough }\end{array}$ & $\begin{array}{l}\text { Knitting machine used } \\
\text { to meet production } \\
\text { targets, and rarely } \\
\text { jammed }\end{array}$ & $\begin{array}{l}\text { Workers have } \\
\text { timeliness in working } \\
\text { the orders that have } \\
\text { been given }\end{array}$ \\
\hline & $\begin{array}{l}\text { Owners are always } \\
\text { quick and responsive } \\
\text { when there are } \\
\text { complaints from } \\
\text { consumers }\end{array}$ & $\begin{array}{l}\text { Raw material (yarn) to } \\
\text { be processed is always } \\
\text { available in number } \\
\text { of orders and avoid } \\
\text { waiting }\end{array}$ & \\
\hline & $\begin{array}{l}\text { Delivery of goods using } \\
\text { the help of others, such } \\
\text { as delivery services } \\
\text { (expedition, cargo, } \\
\text { package) }\end{array}$ & \\
\hline
\end{tabular}

Table 11

The Competitiveness Determining Factors

\begin{tabular}{|c|c|c|c|}
\hline Dimension & Indicator Number & Dominant Factors & Loading \\
\hline Cost & 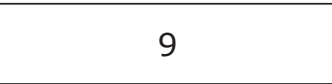 & $\begin{array}{l}\text { Machine / production equipment that fully used } \\
\text { according to order capacity }\end{array}$ & 40,694 \\
\hline Quality & 8 & $\begin{array}{l}\text { Owners are always quick and responsive when } \\
\text { there are complaints from consumers }\end{array}$ & 49,675 \\
\hline Quality & 7 & $\begin{array}{l}\text { Timed trend / model of a product that last long } \\
\text { enough }\end{array}$ & 58,184 \\
\hline Delivery Time & 2 & $\begin{array}{l}\text { Knitting machines used to meet production } \\
\text { targets, and rarely stuck/jammed }\end{array}$ & 65,744 \\
\hline Delivery Time & 4 & $\begin{array}{l}\text { Raw materials (yarn) to be processed are always } \\
\text { available according to order quantity and avoid } \\
\text { waiting }\end{array}$ & \\
\hline Delivery Time & 6 & $\begin{array}{l}\text { Delivery of goods using the assistance of others } \\
\text { such as shipping services (expedition, cargo, } \\
\text { package) }\end{array}$ & 75,618 \\
\hline Flexibility & 4 & $\begin{array}{l}\text { Workers have timeliness in working on orders } \\
\text { that have been given }\end{array}$ & 79,344 \\
\hline
\end{tabular}

of variance of maximized variables becomes more dispersed and evenly distributed so the contribution of each variable to each component is seen more clearly. The highest variable is $79,344 \%$ in the factor of flexibility, thereby the influence of the factors that determine the competitiveness of human resources in improving the productivity of knitting creative industry is 79,344\%, while $20.656 \%$ influenced by other factors that are not dominant.

\section{Conclusions}

Based on the results of the study and discussion on Competitiveness and
Productivity in Binong Jati Knitted Creative Industry Center, it can be concluded that:

There are factors that affect the competitiveness in improving the productivity of knitting creative industry in Binong Jati, namely a) the flexibility factor with one component selected that is the indicator of quick adjustment to the environmental interest; b) on time delivery factor with three components factors selected which are the indicator of timeliness of product delivery, reduction of production waiting time, and timeliness of production; c) the quality factor with two components factors selected which are the indicator of the quick response to consumer complaints and product resilience 
endurance; (d) the cost factor with one component selected that is the indicator of the use of production and inventory capacity.

From several factors that affect the competitiveness in improving the productivity of Binong Jati knitting creative industry, there is one dominant factor that influences the most, that is flexibility factor with the indicator of quick adjustment to the interests of environment since it has the highest value.

There are also seven factors of competitiveness and one factor is predominantly influence the productivity, which is human resource and can be taken into account of consideration in the revitalization of creative industries and city branding in Bandung.

\section{References}

As'ad. (2009). Inter Doiminan Management: First International Conference. https://Books Google.co.id/Books/ isbn $=3540729852$. Oslo-Norway-June 21-02-2007. Proceeding.

Basu, Swastha DH., Irawan. (2008). Manajemen Pemasaran Modern, Edisi 2, Cetakan 13, Liberty Offset, Yogyakarta,

Dumasari., Tri Septin Muji Rahayu. (2016). Management Strategy of Creative Souvenir Micro Enterprise for Empowerment of Craftsmen Peasant, Journal of Mimbar Volume 32, Number 1, pp 175-186.

Dhanny Septimawan Sutopo. (2016). Vitality of Village UMKM in the Arena of ASEAN Economic Community, Journal of Mimbar Volume 32, Number $2^{\text {nd }}$ (December, 2016), pp 412-420.

Fisla Wirda, at.al. (2016). The Influence of
Management Competency and External Environment on Competitive Advantage of a Creative Industries in West Sumatra, Journal of Mimbar Volume 32, Number 1, pp 126-138.

Frans Gana,(2003).Inovasi Organisasi Sebagai Basis Daya Saing Bisnis, Usahawan.

Ghozali, Imam. (2011).Aplikasi Analisis Multivariate Dengan Program IBM SPSS 19, edisi kelima, Semarang: Universitas Dipenegoro.

Greenberg. (2009).Simplle Skill for Peace and Productivity. https://BooksGoogle.co.id/ Books/isbn $=0393719890$.

Kompas.com. (2016). Pertumbuhan Ekonomi 2015 Terendah dalam Enam Tahun Terakhir. Diunduh Oktober 5. 2016, dari http://bisniskeuangan.kompas. $\mathrm{com} / \mathrm{read} / 2016 / 02 / 07 / 182803626 /$ Pertumbuhan.Ekonomi.2015.Terendah. dalam.Enam.Tahun.Terakhir

The OECD. (2009). Measuring the CapitalOECD Manual. Second Edition. https://BooksGoogle.co.id/Books/ isbn $=9264068473$.

Porter, Michael E.(1990). The Competitive Advantage of Nations, The Macmillan Press Ltd, London

Riduwan dan Sunarto. (2012).Pengantar Statistik untuk Penelitian Pendidikan, Sosial, Komunikasi, Ekonomi, dan Bisnis. Bandung: Alfabeta. Jakarta

Suhardi. (2007). Skripsi. Universitas Sumatera Utara.PT Salemba Empat.

Sunarto. (2004). Prinsip - Prinsip Pemasaran. Yogyakarta: Amus.

Ward et.al. (1998). The Nature of Supplay Chain Management Research: Insights from a Content. P 1037. https://Books Google.co.id/Books/isbn $=3834977471$. 